\title{
The Translatability of Military Expressions by B.A Students at Zarqa University in Jordan
}

\author{
Ibtehaj.M. Akhoirsheda (first author) \\ Part time instructor at Hashemite University, P.O Box 11942 Jordan. Amman
}

\begin{abstract}
The study aims at investigating the level of Zarqa University students in translating military expressions from English into Arabic and vice versa. Moreover, The study aims to reveal some of the problems that students may encounter while translating military texts and to investigate the Gender effect on the translation of students. The researcher distributed a questionnaire consists of 15 English military expressions and 10 Arabic military expressions. The sample of the study includes 25 B.A students (Male and Female) at the Department of Translation at Zarqa University. The results of the study has shown that Polysemy and Synonymy are the main problems that students encountered while translating military expressions. Furthermore, the study reveals that being male or a female has no effect on the military translation.
\end{abstract}

Keywords: Translatability, Military, Expressions, English, Arabic, Zarqa

DOI: $10.7176 /$ RHSS/11-4-04

Publication date: February $28^{\text {th }} 2021$

\section{Introduction:}

Inaccurate translation of military orders or texts will have a serious consequences, hence the importance of training translators. According to Nida (1969), he defines translation as a process of reproducing in the TL the closest natural equivalence. that is why In translating military texts the translator should be familiar with military jargons, and have a background knowledge in the military field. Al- Shehab (2014, p.56). :

"military translation has played a crucial role since the early days of Islamic growth, Muslim armies benefited greatly from the expertise of the translators they encountered in the nations they conquered. The armies moved through areas with different languages and cultures. Despite the fact that Arabs have had a very rich military history, they had to depend on foreign armies to develop and modernize their armies. As a result, they had to keep up with the massive inflow of new military technology and terminology".

This research thoroughly examines difficulties that translators encounter while translating military orders and texts, and investigate the most suitable strategies to translate military expressions, and examines the differences in the ability for both genders in translating military texts.

\subsection{Statement of the Problem:}

Military translation is an important issue, catastrophic consequences can happen if the translator made any kind of mistake, this why the researcher find interest in investigating the difficulties faced by translators in translating military expressions as an example, " Crown", which means "flash hider" (فنجان مخفي اللهب). In another example, قاعة الطعام للعسكريين, which means "Dining Facility"( DFAC).

\subsection{Objectives of the study:}

1. what is The level of Zarqa University students in translating military expressions

2. what are the difficulties that students of Zarqa University encounter while translating military expressions

3. Examining Translation methods used by students in translating military terms.

4. Investigating the gender impact in military translation ability.

\subsection{Significance of the study:}

The importance of this research come from that there are only few studies on this topic, and the students lack of knowledge of military expressions. And the rapid advancement of the military field, this study came to investigate the challenges faced by the students in $\mathrm{ZU}$ while translating military terms, and study the strategies that is used in the translations, so that translators can overcome the challenges

\subsection{Limitation of Study:}

The researcher faced the following limitations:

1. There had been only a few studies on Military translation, therefore references were limited.

2.The sample size of this study is small, and only included BA students. 


\section{Methodology:}

\subsection{Data collection}

The methods that are used for the data collection for this study is a questionnaire, and some data collected from official military branches, as well as interviews made with some military officers working in the translating fields.

\subsection{Data analysis}

The researcher of this study adopted the descriptive and the analytical method, as well as the collected data will be analyzed and classified, this study will review the difficulties students face while translating military terms, and examining Translation methods.

\section{Theorytical background \\ 3.1 Translation}

Translation is considered a process of transferring meaning from one language to another, and it is what makes exchanging information between users of different languages possible, therefore, translators aim to produce in the target TL the most natural text. Nugroho (2007) defines translation as "An effort of finding equivalent meaning of a text into the second language" $(\mathrm{P}, 66)$. the main aim of a Translator is to catch the meaning and convey it in the most natural way. Translation methods and techniques vary, and the techniques that one translator may use to reach that equivalency in meaning may not be used by another translator, Malkawi (2000, p. 15) mentioned the following methods of military translation:

Literal Translation Method: in which the SL form and content is preserved.

Meaning Translation Method: it attempt to convey the meaning of the SL, forgetting about the literal meaning and the form of the text

Explanatory Translation Method: which means beside translating the term that you explain it to the audience.

\subsection{Military Translation}

Military translation is considered a type of science translation and requires a thorough knowledge of military science Malkawi (2000, p. 35). The researcher believes that military translation needs to be highlighted, considering its fast growth, and the massive increasing in new expressions due to the arms industry and war innovations. military translation is considered an important issue within the translation field, it has a significant impact on our life, it is widely used nowadays in global media, movies and video games. This study hopefully will introduce students to the military translation and make them overcome any problem they encounter in translating military text, and will help them more in understanding the translating methods used in military translation.

Bell (2006) says that military terms is what used by military organizations and military personnel. AlKaabi (2008, p.18) explains that the origin of military translation expressions were coined during wars and conflicts of the 20th century, and many of these expressions are the names of new weapons, and military innovations, all of this led to the need to translate military expressions to enable the soldiers to know how to use the weapons.

Catford, (1965, p. 94) points out that to achieve a professional translation you have to be trained in the related field of translation, in this case it is the study of military translation, and the need for a good experience before you translate, Al- Kaabi (2008, p.18) explained that military translation requires experienced translator in the field of military with a deep knowledge, and this actually was discussed in the previous studies such AlShehab (2009,2014), Al- Maani (2015) and Magableh(2017) they have indicated that university students have a fair level in translating military texts, since students lack the necessary experience and knowledge, their studies were in Sultan Qaboos University in Oman, and Yarmouk University in Jordan, and Jadara University, and they have suggested taking into consideration military translation courses as a technical type of text in the English departments.

Many researchers investigated military translation, and the problems that students might encounter while translating, and according to Al-Shehab (2014) the study shows a high level of polysemous problems that translation students have encountered while Attempting to find the suitable equivalence in the TL. Al-Maani (2015) points out that students usually excessive reliance on dictionaries, which leads to low level of translating, and emphasize the importance of the context in a effecting the meaning, He further explained that students may encounter problems when it comes to words which are not yet Arabicized because the dictionaries in the Arab world are not updated regularly.

Al-Kaabi (2008) explains that military expressions translation is really important, considering the need of translating special knowledge when a new weapons are invented, which are highly technical, so it can function properly. With fresh weapons and the exports and imports between states, which includes weapons specifically produced to assume a specific military task. This dictates the need to be well informed of the instructions to 
operate the weapon. Magableh(2017) points out that the need for military translation emerges from the over-rely of developing countries on importing weapons from the first world countries.

Al-Maani (2012) inaccurate translation of technical documents might lead to a serious effect on who depends entirely on the material translated into the TC [Target Culture].

Jalabneh (1991) The study reveal that military translators use more than one method of translation when dealing with military texts. This research also points that military translators focusing on translating the main ideas in the text instead of focusing on literal translation.

Jalabneh (1991) points out that the Arab Military Academies have released pamphlets and compiled dictionaries for military terms. This indicates how important it is that we clearly understand military terms and be able to find the most natural and closest equivalence for a certain term. As well as that (Al-shehab 2009) mentioned that it is really important to find new terms for the developed Arab armies, since that they have adapted the structure of their military forces from different Western and Eastern modern armies, he added that Arab language academies worked on finding new terms and translations for the new military terms and jargons, those efforts were carried out by the Academy of the Arab Language in Damascus (1919), the Academy of Arab language in Cairo (1934), the Scientific Academy of Iraq (1948), the Academy of the Arab language in Amman (1980), and the Academy of Bait Al-Hikma in Tunis (1983).

By reviewing related literature studies, the researcher came across many ideas regarding the field of translating military expressions, some studies were concerned with the quality of translating military expressions such as Dr. Mohammad Alshehab research paper (2014), where a sample of MA students were chosen from Yarmouk university to examine the level of students ability to translate military expressions, many other studies were made such as Jalabneh's study (1991), Al-Imian's study (2014) and Magableh (2017).

This subject has been dealt with in the academic field by Al- Shehab (2009); Magableh(2017);Alshishani(2018) they investigated the difficulties encountered while translating military expressions in the Jordanian Academy, with deference's between them, Al-Shehab (2014) has examined Yarmouk University students' ability in translating military expressions from English into Arabic.

Magableh(2017) has examines The Translatability of Military Expressions and Texts from Arabic into English and Vice Versa by Translation Students at Jadara University in Jordan.

Al-Shishan(2018) he had studied problems of translating military expressions that students of Zarqa University encounter while translating, this study was limited by only translating expressions from English into Arabic.

All of those studies and researches enrichened the researcher with ideas and benefited the present research greatly as that it helped understanding military translation.

This study is based on the recommendations suggested by Magableh(2017) calling for further study in this area to investigate the gender impact in military translation ability. This study will be also concerned with examining the difficulties that students Zarqa University encounter while translating military expressions from English into Arabic and vice versa.

\section{Analysis and Discussion}

This part of the study focuses mainly on analyzing the data collected by using a questionnaire .The questionnaire was distributed to 4th year translation students at Zarqa private university, the disturbed questionnaire contained different military expressions the students were given this test and were asked to translate it within 20 minutes by using dictionaries, The questionnaire was made of 15 expressions to be translated from English into Arabic, and 10 expressions to be translated from Arabic into English. The sample of the study included 25 Bachelor translation students (Male and Female) for the English into Arabic military translation test, and 20 Bachelor translation students for the Arabic into English translation test. It should be pointed out that the test was reviewed by a military translator and his remarks have been taken into consideration.

Table (1)

English into Arabic Translation Text Scoring Criteria

Professional Translation

Excellent

$15-11.25$

\section{Students' Translation}

\begin{tabular}{l|l}
\hline Fair & Unacceptable \\
\hline
\end{tabular}

2

$7.49-3.75$

The table above indicates that the questionnaire mark is out of 15 , if the students' scores were within the range of $(15-11.25)$, the translation is considered approximately equivalent to professional translation, and his/her level is excellent. The expression scores (1) mark if it was excellent translation and it is within the fourth criterion, and if the scores were within the range of (11.24 -7.50) the student level is considered acceptable, and it is within the third criterion, , the expression in this case scores (.75)as a mark. If the expression rendering was partly right it is considered fair and it scores (.50) as a mark. The last criterion which is Unacceptable in this case 
the translation is completely wrong, so it scores (.25).

4.1. Answering The first question of this research, what is The level of Zarqa University students in translating military expressions, The percentages of students scores is shown in Table (2)

Table (2)

Students' level in translating military expressions from English into Arabic at Zarqa University in Jordan

\begin{tabular}{|c|c|c|c|c|}
\hline NO. & Grade & Percentage & Gender & Rank \\
\hline 1 & 10 & 66.6 & $\mathrm{~F}$ & 7 \\
\hline 2 & 9.25 & 61.6 & $\mathrm{M}$ & 10 \\
\hline 3 & 10 & 66.6 & $\mathrm{M}$ & 7 \\
\hline 4 & 11.25 & 75 & $\mathrm{~F}$ & 3 \\
\hline 5 & 7.25 & 48.3 & $\mathrm{M}$ & 13 \\
\hline 6 & 10.50 & 70 & $\mathrm{~F}$ & 5 \\
\hline 7 & 9.75 & 65 & $\mathrm{~F}$ & 8 \\
\hline 8 & 9.75 & 65 & $\mathrm{~F}$ & 8 \\
\hline 9 & 11.75 & 78.3 & $\mathrm{M}$ & 2 \\
\hline 10 & 12.25 & 81.6 & $\mathrm{~F}$ & 1 \\
\hline 11 & 10.25 & 68.3 & $\mathrm{~F}$ & 6 \\
\hline 12 & 8.50 & 56.6 & $\mathrm{M}$ & 12 \\
\hline 13 & 10 & 66.6 & $\mathrm{~F}$ & 7 \\
\hline 14 & 7.25 & 48.3 & $\mathrm{M}$ & 13 \\
\hline 15 & 9 & 60 & $\mathrm{~F}$ & 11 \\
\hline 16 & 10.50 & 70 & $F$ & 5 \\
\hline 17 & 8.50 & 56.6 & $\mathrm{~F}$ & 12 \\
\hline 18 & 9.50 & 63.3 & $\mathrm{~F}$ & 9 \\
\hline 19 & 10.75 & 71.6 & $\mathrm{~F}$ & 4 \\
\hline 20 & 9.50 & 63.3 & $\mathrm{~F}$ & 9 \\
\hline 21 & 9.75 & 65 & $\mathrm{M}$ & 8 \\
\hline 22 & 10.25 & 68.3 & $\mathrm{~F}$ & 6 \\
\hline 23 & 10.75 & 71.6 & $\mathrm{~F}$ & 4 \\
\hline 24 & 9.75 & 65 & $\mathrm{~F}$ & 8 \\
\hline 25 & 10 & 66.6 & $\mathrm{M}$ & 7 \\
\hline
\end{tabular}

This study was conducted on a (25) 4th year students. As illustrated in the table above the level of Zarqa University students is: $(4 \times 3+3 \times 20+2 \times 2+1 \times 0) 76 \%$ which is considered positive, where as 3 students were in the 4 criterion, 20 were in the third, 2 were in the second and non of the students were in criterion no. 1.

surprisingly the level of Zarqa University students in translating military expressions is $76 \%$ which is considered a good level, while all the previous related studies as Al- Shehab (2009, 2014), Magableh (2017) indicated that university students abilities in military translation is considered fair.

The following table shows some of the students translation of military expression from English into Arabic.

Table (3)

Examples of students' English into Arabic translation

\begin{tabular}{|c|c|c|}
\hline $\begin{array}{l}\text { Item } \\
\text { No. }\end{array}$ & Students Translation & Suggested Translation \\
\hline 1 & $\begin{array}{l}\text { " The barracks was surrounded by a high wall" } \\
\text { Is translated as: "معسكر ات" }\end{array}$ & "التكنات العسكرية " \\
\hline 2 & $\begin{array}{l}\text { "We are at the zero hour, so someone has to make a decision" } \\
\text { Is translated as: "الساعة الحاسمة" }\end{array}$ & "ساعة الصفر" \\
\hline
\end{tabular}

In the first example, one of the students translated it into " معسكر ات", which is not acceptable in translating military text, while it is translated as "ثكنات عسكرية". The second expression was translated by another students into "الساعة الحاسمة", while the correct translation is " ساعة الصفر", which literal translation and this explain why most students translated it a correct way.

The researcher believes that students were incapable to find the suitable equivalence for some of the English military expressions, because some of these expressions are used only in the US army, "the retreat ceremony" for instance, is an military expression which means the flag is lowered, "تنزيل العلم , this term is not used in Arab countries, so it's not enough to have a background knowledge in military in general, but you also have to be familiar with the culture of the military you are dealing with. 
Table (4)

Arabic into English Translation Text Scoring Criteria

Professional Translation

Excellent

4

$10-7.50$

\begin{tabular}{|l|}
\hline Acceptable \\
\hline 3 \\
\hline $7.49-5$ \\
\hline
\end{tabular}

\begin{tabular}{|l|l|}
\hline Students' Translation \\
\hline Fair & Unacceptable \\
\hline 2 & 1 \\
\hline $4.99-2.50$ & $2.49-0$ \\
\hline
\end{tabular}

As shown in Table (5), none of the students obtained excellent nor unacceptable level, where as 11 student were acceptable and 9 students were fair.

Table (5)

Students' level in translating military expressions from Arabic into English at Zarqa University in Jordan

\begin{tabular}{|l|l|l|l|l|}
\hline NO. & Grade & Percentage & Gender & Rank \\
\hline 1 & 5.50 & $55 \%$ & F & 4 \\
\hline 2 & 3.75 & 37.5 & F & 10 \\
\hline 3 & 5.25 & 52.5 & F & 5 \\
\hline 4 & 5.25 & 52.5 & M & 5 \\
\hline 5 & 4.25 & 42.5 & M & 8 \\
\hline 6 & 4.50 & $45.0 \%$ & F & 7 \\
\hline 7 & 5 & $50.0 \%$ & F & 6 \\
\hline 8 & 5.25 & 52.5 & M & 5 \\
\hline 9 & 7 & 70 & M & 2 \\
\hline 10 & 3.75 & 37.5 & F & 10 \\
\hline 11 & 5.25 & 52.5 & M & 5 \\
\hline 12 & 6 & 60 & M & 3 \\
\hline 13 & 7.25 & 72.5 & M & 1 \\
\hline 14 & 4 & 40 & F & 9 \\
\hline 15 & 4.50 & 45. & M & 7 \\
\hline 16 & 5.50 & 55 & M & 4 \\
\hline 17 & 4.0 & 40 & F & 9 \\
\hline 18 & 4.50 & 45 & M & 7 \\
\hline 19 & 4.25 & 42.5 & 5 & 4 \\
\hline 20 & 5.50 & 55 & & 8 \\
\hline
\end{tabular}

Zarqa University students level in translating military expression from Arabic into English is $(\mathbf{0} \times \mathbf{4}+\mathbf{1 1} \times \mathbf{3}+\mathbf{9} \times \mathbf{2}+\mathbf{0} \times \mathbf{1})=\mathbf{5 1 \%}$ which is considered fair level, but low comparing to their level in translating from English into Arabic, as expected cause Arabic is their mother tongue so they can play with words.

These results are mentioned in previous related studies as Al- Shehab $(2009,2014)$ and Magableh (2017).

The following table shows some of the students translation of military expression from Arabic into English.

Table (6)

Examples of students' Arabic into English translation

\begin{tabular}{|c|c|c|}
\hline $\begin{array}{l}\text { Item } \\
\text { No. }\end{array}$ & Students Translation & Suggested Translation \\
\hline 1 & $\begin{array}{l}\text { "يجب ان يحتوي الكانتين على جميع احتياجات الافر اد داخل الوحدة "Military historiography" } \\
\text { Is translated as: "Mrilisy }\end{array}$ & " canteen" \\
\hline 2 & $\begin{array}{l}\text { "يجب تأمين أرزاق مرزومة للأفر اد تكفي لمدة } 48 \text { ساعة "supplies" } \\
\text { Is translated as: " }\end{array}$ & "packed food" \\
\hline
\end{tabular}

In the first example one student shockingly translates it as "military historiography" which is not related to military translation or the term itself in any kind of way, most of the students translated it as" canteen". The second term is" أرزاق مرزومة "another student translated it as " supplies - مؤونات while the correct translation is "packed food".

4.2. Answering the second question of the study : what are the difficulties and problems the student of Zarqa University encountered while translating military expression from English into Arabic?

4.2. 1. Polysemy

Magableh (2017) has indicated in his Thesis grammar, syntax and polysemy problems that encounter students 
while translating military expression. When a term has multiple senses, and the text is a science type of text in our case its military translation, with no background knowledge of the field, students main problem was polysemy. To illustrate my point the expression crown in the: SL" the crown is the most important piece in our

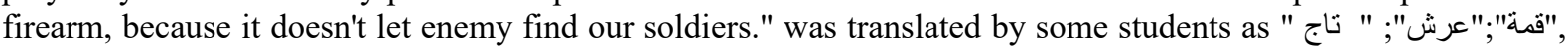

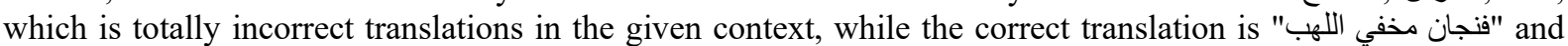
this particular translation is not found within machine translation it only could be obtained through military experience and special military dictionaries. In another example SL:"The soldiers went to shooting range, and they are waiting the command so that they can charge their weapons and shoot" in this sentence the term charge was translated by one student as "تهمة", which is unacceptable translation and suit better in a legal kind of text, the correct equivalence for this term is" سحب السلاح وتجهيزه".

\subsubsection{Synonymy}

Through this study the researcher believes that in military kind of text each term has a certain equivalence, and to some extent military translation is limited by the use of the exact appropriate equivalence to avoid ambiguity, students of Zarqa University encountered a problem in selecting the most suitable equivalence that fits military text, due to the use of machine translation. in one example SL:"When i was 25 years old, i was a company commander in 7 first battalion." some students translated the expression "company" as "كتيبية" which is incorrect and has its own jargon " Battalion", one of the students translated it as" وحدة عسكرية" which hardly gives part of the meaning, the correct translation of this term is "سرية". In another example SL:"Apparently, even an expert marksman like you still has a thing or two to learn about tactics." some students translated the expression marksman as " قتاص" which is the meaning of " sniper ", while the suitable equivalence is "رام" .

\section{2.3. Grammar}

Most of the students had no Spelling mistakes, one student wrote "solders" instead of " soldiers". another student wrote mobilization while the correct spelling is " mobilization". Overall it was a minor issue .

\subsubsection{Syntax}

Some of the students encountered a problem related to the" word order" Magableh (2017) noted this problem in his thesis. For example SL:" the soldiers always clean their weapons after shooting, and put them in the armory. " one of the students translated it as " الجنود بعد الرماية ينظفون اسلحتهم دائما ويضعونها في العهدة" he made mistakes on different levels, first the student started the sentence using a noun which is incorrect cause he adopted the English style while translating Arabic sentence, while he should of started with the verb, which is more like the

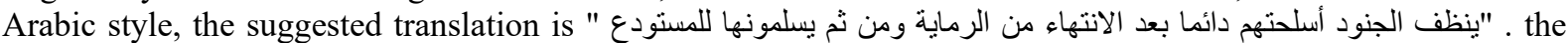
student made another mistake by translating the term "Armory" into "العهدة " which is considered partially correct, but this term is not exclusively used for the weapons but also for the uniform, the correct translation for it is

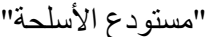

Additions

For example one student translated SL:"There were many destroyed tanks in World War II." into " كان هناك العديد " القديمة " the student here added the word is not mentioned in the original sentence, in another example SL:"For safety and tactical reasons, these helicopters always operate in pairs." one student translated it as " لأسباب تكتيكية و السلامة استر اتيجية عمل طائر ات الهوليكوبنر بشكل مزدوج the student here made a lot of mistakes here firs he added the word " " wich change the meaning, and unneeded information, " مزدوجج" means in Arabic that you do two things in the same time or could mean it works for two countries which is not the case here the suitable word is" pairs - على شكل أزواج " the suggested translation is " "لاوو اعي السلامة و الأسباب التعبوية تعمل هذه الطائر ات العمودية على شكل أزواج

Omissions

In one example SL:"My platoon is in mission, and has a guard duty ", one student translated it as " وحدتي في مهمة

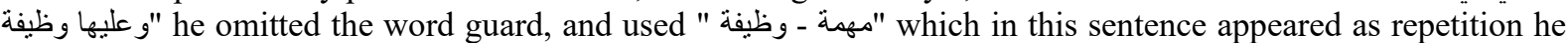
could used only one. the suggested translation is "فصيلي في مهمة وعليه واجب حماية و platoon as" وحدة" is not correct the correct expression is " فصيل و و

4.3. Answering the third question of the study: students in military translation from English into Arabic: Malkawi (2000, p. 15) mentioned three methods of translation military term: Method of Translation used by

\subsubsection{Literal translation method}

Most of the students adopted the literal translation method which means the transfer of the form and the content of the SL. for example SL:"It has been a long march, so the soldiers were weary." was translated by students as" " لقد كانت مسيرة طويلة لذلك كان الجنود متعبين "which is considered a correct translation, and also as mentioned before the

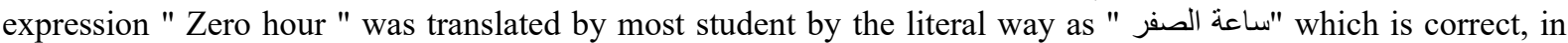
another example SL:"Squeeze the trigger" students translated it as" اضغط على الزناد ". on the other hand in the SL:"Tell that to the marine." which is an idiomatic expression the literal translation is not acceptable, 23 student translated it as:"أخبر مشاة البحرية بذلك" only two students used the Meaning Translation method. 


\subsubsection{Meaning translation method}

Meaning translation means the transfer the meaning caring only to the TT, when the translator do management to the text. as mentioned before SL:"Tell that to the marine" which is an idiom and was translated by only two students as:" لن يصدقلك احد, كفاك كذبا " which is a correct translation surprisingly these were female students.

\subsubsection{Explanatory Translation method}

explanatory translation is when the translator add explanation to the translated term, one student actually used this method in translating SL:"Zero hour" as "ساعة الصفر أي ساعة البدء" .

\section{4. what are the difficulties and problems the student of Zarqa University encountered while translating military expression from Arabic into English?}

\subsubsection{Polysemy}

From Arabic into English translation students main problem was polysemy, for example the SL:" يجب على كلى some students translated the expression" "مراجعين القيادة العامة للقوات المسلحة التقبد باللباس الموسمي التكميل "supplementation." which is incorrect translation for this term in the given context, the correct translation is "Class "A" dress". in another example SL:"على جميع أفراد الوحدة إستلام العهدة وتوقيع وصل الاستلام" some students translated it as "Custody" and one student shockingly translate it as "promise" both of these translations are unacceptable, the correct translation is "Military dress".

\subsection{2. synonymy}

Some student translated SL:" تتفاوت خطط التعبئة العكرية لدى الجيوش على مر الازمنة انطلاقا من موقف عدوها المحتمل

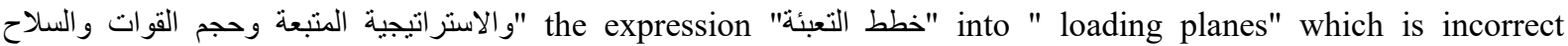
translation in military text the correct translation is " mobilization plans".

\subsection{Method of Translation used by students in military translation from Arabic into English}

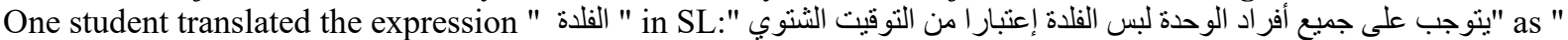
Felda" he used the Transliteration method which is incorrect the correct translation is " Jacket".

in another example SL:"خذ as "خذ الأرض "some student translated the term" "take the earth " using literal translation which changed the meaning, the correct translation is prone" some students translated it as " lay down" which is correct cause it give the meaning .Another example the term "يقظة" in SL:"يتوجب على هيئة الخفر عمل يقظة صباحية ليس بعد شروق الشمس" is translated by most of the students as "wake up" using literal translation and its considered unacceptable translation the correct translation is "Circle defense" only a person with military experience would know the correct translation, only one male student translated it as "Morning watch " which is considered correct translation.

In the SL:"القطعة" was translated by some students as " piece" facing polysemy problem here and using literal translation, the correct translation is " the prison" using meaning translation, which again require military knowledge to catch the meaning.

surprisingly some students understood the term " مرتب and in the SL:"سيعطي القائد محاضرة لجميع مرتب الوحدة" and translated it as " salary" though through the given context there is no way it could be translated as salary, so the researcher think what cause the problem here is using machine translation, the correct translation is " all members of the unit".

4.6. Answering the fourth question of the study: examining differences in military translation ability in light of Gender. this part of the study was based on the recommendations suggested by Magableh (2017) calling for further study in this area,

Translating military expressions from English into Arabic:

As shown in table (2), Female level is $74.25 \%$ which is considered acceptable, where as male level is 63.75 which is fair. The table, thus, depicts the trend that females scored higher as compared to males.

Translating military expressions from Arabic into English:

As shown in table (5), Female level is $50.83 \%$ which is a fair level of translation, while male level is $51.04 \%$ which is fair level. here males score was higher than females.

As BA students it was expected that males would have a higher score than females, considering that males usually have more military knowledge than females, but as shown a above it wasn't the case.

Bottom line is being male or female has no effect on the military translation ability whatsoever, it only depends on military experience and knowledge.

\section{Conclusion:}

This study is an attempt to investigate the level of Zarqa University students in translating military expressions from English into Arabic and vice versa and to review some of the problems that students encountered while translating military text, and to investigate the Gender effect on the ability of translating military expressions. The researcher distributed a questionnaire made of 15 expressions to be translated from English into Arabic, and 
10 expressions to be translated from Arabic into English. The sample of the study included 25 Bachelor translation students (Male and Female) for the English into Arabic military translation test, and 20 Bachelor translation students for the Arabic into English translation test.

The results of the study showed that:

1. The level of Zarqa University students in translating military expressions from English into Arabic is $76 \%$ which is considered positive.

2. The level of Zarqa University students in translating military expressions from Arabic into English is $\mathbf{5 1 \%}$ which is considered fair level.

3. Polysemy and Synonymy were the main problems that students encountered while translating military expressions.

4. Gender has no effect on the military translation ability, it only depends on military experience and knowledge.

\section{References}

Al-shehab, M.(2014)."The Translatability of Military Expressions by M.A.SS in Translation at Yarmouk University in Jordan". International Journal of Comparative Literature \& Translation Studies.

Al-Shehab, M.(2009). "Issues in Translating Military Expressions and Texts between English and Arabic". Unpublished PhD Thesis, University of Science and Technology, Malaysia

Jalabneh, M.(1991)." A Study in The Issue of Military Translation. Amman,Dar- AL Khawajah.

Al-Maani, T.(2014)."Problems and Strategies of Translating English Military Texts into Arabic". Unpublished M.A. Thesis, The University of Jordan, Amman.

Al-Maani, M. (2015). "The Contextual over the Referential in Military Translation". English Language Teaching.

Al Kaabi, R. (2008). "Translating English military neologisms into Arabic". Unpublished PhD Dissertation, Department of Translation, College of Arts, Al-Mustansiriyh University- Iraq.

Al-Shehab, M. (2013)."The Impact of Language Planning, Expressions Planning, and Arabization on Military Expressions Planning and Translation". Journal of Research on Humanities and Social Science.

Magableh, F. (2017)."The Translation of Military Expressions and Texts from Arabic into English and Vice Versa" M.A. Thesis, Jadara University . Irbid.

Al-Shishani, A. (2018)." Problems of Translating Military Expressions". Unpublished Thesis, Zarqa University . Zarqa.

Malkawi, H.(2000)."Military Translator Guide". Dar Aljamal.

\section{Notes}

Zarqa University

Faculty of Arts

The department of Translation

TEST

The following test and questionnaire are administrated for research purposes; your contribution will be greatly appreciated. As the tested students will be kept strictly confidential, please DO NOT WRITE YOUR NAME.

Translate the following sentences into Arabic:

1. Crown

a) The crown is the most important piece in our firearms because it doesn't let enemy find our soldiers.

\section{Company}

b) When i was 25 years old, i was a company commander in 7 first battalion.

\section{Barracks}

c) The barracks was surrounded by a high wall.

\section{Charge}

d) The soldiers went to shooting range, and they are waiting the command so that they can charge their weapons and shoot.

\section{Platoon}

e) My platoon is in mission, and has a guard duty.

\section{Retreat}

f) The retreat occur in my unit at $6 \mathrm{am}$. 


\section{March}

d) It had been a long march, so the soldiers were weary.

\section{Tank}

e) There were many destroyed tanks in World War II .

\section{Armory}

f) After shooting the soldiers always clean their weapons, and put them in the armory.

\section{Infantry}

g) We was second infantry unit together in Afghanistan..

\section{Marksman}

h) Apparently, even an expert marksman like you still has a thing or two to learn about tactics.

\section{Squeeze the trigger}

i) So I just point, and then I squeeze the trigger and then boom.

\section{Quarter Master}

j) That'll be all, Quartermaster

\section{Tactical}

f) For safety and tactical reasons, these helicopters always operate in pairs.

\section{Tell that to the marine}

\section{Zarqa University \\ Faculty of Arts \\ The department of Translation \\ TEST}

The following test and questionnaire are administrated for research purposes; your contribution will be greatly appreciated. As the tested students will be kept strictly confidential, please DO NOT WRITE YOUR NAME.

Translate the following sentences into English:

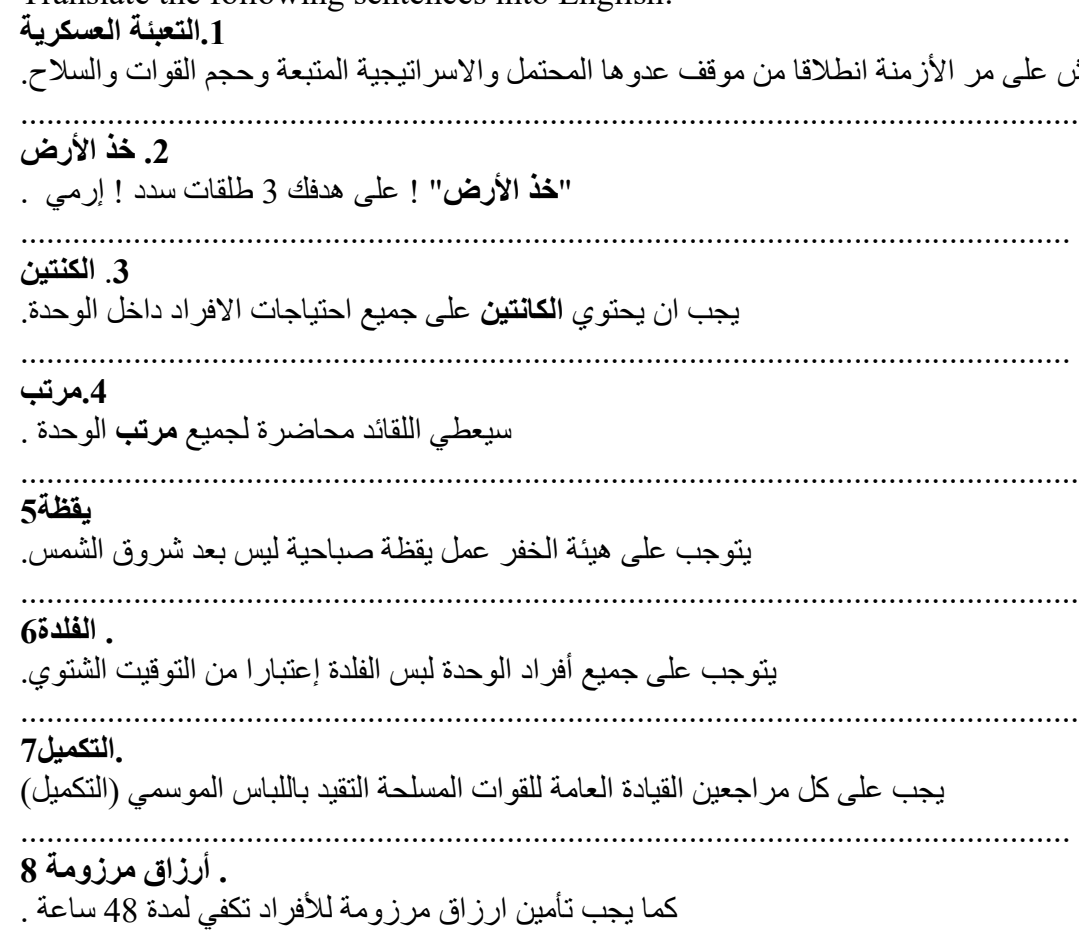

\section{Translation Students \\ 4th year BA \\ GENDER( F / M )}




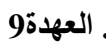

على جميع أفراد الوحدة إستلام العهدة وتوقيع وصل الاستلام .

القطعة 10

كل من يخالف تعليمات الوظيفة الرسمية يوضع بالقطعة لحين محاكمته. 